\title{
Exploration on Joint Course Construction based on the Improvement of Inclusive Education Teachers' Ability
}

\author{
Zhu Mei, Ren Rui \\ Institute of Psychological and Educational Science, Zaozhuang University \\ Zaozhuang, 277160
}

\begin{abstract}
Protecting every child, especially the educational rights of children with special needs, has become an important sign of measuring a country's material and spiritual civilization. Inclusive education is the most effective way to realize these objectives, and the best effective supports and security for inclusive education are high-quality of teachers. Based on inclusive education concepts and teachers' professional qualities, the study draws lessons from the "double certificate" training mode of the United States, combines application-oriented training and industry needs, centers on the inclusive education teachers' professional ability to build joint courses with an interactive teaching system. Teachers and students build a learning community through the classroom and the network platform, in order to promote the integration of interactive teaching system theory and practice, to achieve the integration of pre-service training and in-service training. It also provides curriculum support for web-based learning for the educator of special education institutions, kindergartens, and communities.
\end{abstract}

Keywords-Inclusive education teacher; Joint course; Learning community; Professional ability

\section{INTRODUCTION}

Inclusive education teachers, refers to teachers who can meet the needs of diverse students in ordinary classrooms, including special children with special educational needs. These teachers not only have the literacy of general education teachers, but also can carry out special children's education tasks. For a long time, the system of Chinese general education teacher training and special education teacher training is independent from each other. According to the survey on the establishment of special education courses in ordinary normal colleges, only 19 out of the 137 normal colleges have established special education compulsory or elective courses, accounting for $13.9 \% .118$ have not yet established, accounting for $86.1 \%$ of the total [1]. Even if special education courses are offered, the courses are mainly based on the ladder structure of foundation and application, theory and practice, lacking necessary mutual cares. Repetition and omissions are inevitable. The response to industry needs and professional abilities only appears in little practice teaching processes, and learning is isolated from professional life. The teacher himself is full of strong frustrations and his professional identity is generally low. This not only makes children with special needs in chaos, but also loses interest and confidence in learning. At the same time, teachers are generally worried about their ability to engage in inclusive education. The quality of teachers has become an important factor hindering the development of inclusive education.

With the transformation of teacher training from "normal education" to "teacher education" in China, it is obviously impossible to continue the curriculum system of the traditional normal education training mode. The training or pre-service training, in order to enable ordinary teachers to have inclusive educational ability, only increase the number of courses, which inevitably increases the burden on teachers. The lack of preservice training in practice makes it difficult for new recruited teachers to adapt to their jobs.

Today, the concept of inclusive education from "complete integration" to "appropriate integration", is more calm and reasonable. The curriculum of the teacher major, through the combination of classroom teaching and network platform, from the inclusive education teachers' professional competence, construct a joint course, to optimize the interactive curriculum teaching in and out of class, on-campus and off-campus, in theory and practice. It not only helps the realization of the application-oriented training, but also promotes integration of the pre-service and post-service training. At the same time, it can realize resource sharing, serve the society, and realize the field construction of school, family and community education with special needs children, and enhance the professional happiness of the inclusive education teachers.

\section{BASIS OF JOINT COURSE}

On the theoretical level, the first basis is the concept of inclusive education. Since "inclusive education" was proposed by Stainback in 1984, China has experienced the development of "original ecology - westernization - localization". The spirit of inclusive education changed from general education for all special children to "general education + effective special education"[2]. New and higher requirements are put forward for in-service teachers and pre-service teachers.

Secondly, the concept of life-long education, Chinese traditional normal education has always been a one-time final education centered on the pre-service trainings of teachers, ignoring the teacher's post-service trainings and life-long 
education. The construction of joint courses can realize the integration of pre-service and post-service teachers trainings.

Thirdly, it based on William Dole's post-modern curriculum concept. The construction of joint courses, based on the integration of classroom and network platform, coincide with a combination of post-modern curriculum concept. It focuses on the recyclability of curriculum, develops the ability of learners [3], and focuses on the process of teachers and students participating in the exploration of knowledge, emphasizes the development, flexibility and interdisciplinary and integrated development of the curriculum[4].

The empirical level is particularly important. It's mainly in the following aspects.

\section{A. Policy promotion}

Following the "Special Education Promotion Plan (20142016) " forwarded by the State Council in 2014, it was further clarified that it is necessary to promote inclusive education, and "improving the professional level of teachers" as an important part of the plan. In July 2017, "the second issue, the special education promotion plan (2017-2020) " was introduced. It requires that the enrollment rate of compulsory education for disabled children reaches $95 \%$ or above. For children and adolescents of school age who are unable to attend school and need special care, they should be sent to the community, or the child welfare institutions and families to implement education.

\section{B. The Enlightenment of American "Double Certificate"}

As early as 1974, the US federal government has promulgated the "President's Fund" to support the state's teacher education institutions to change the situation in which the general education teachers and special education teachers are completely independent, and to some extent achieve the convergence and integration. "Double-certificate" completely merged the training of general education teachers and special education teachers. All students who want to engage in teacher professions can participate in the same training program. After graduation, they can obtain the dual qualifications of both general education teachers and special education teachers[5].

\section{Higher requirements for professional literacy}

Teacher professional literacy is an important standard to measure the professional level of teachers. It is the mainstream trend of teachers' "professionalization" development. The "learning community" composed of learners and assistants can provide practical effective way for teachers' professional literacy. At present, although some colleges have realized the cultivation of the special abilities of students of ordinary teachers' education, most of them carry out universal education in the form of special education elective modules. The class hours are limited, and the training of practical ability is also ineffective. In order to cultivate the professional ability of the inclusive education teachers and improve their professional competence, it is necessary not only to break the mutual isolation and non-interference between the general education and special education modules, but also to break the isolation between outside-of-classroom teachers and students. Therefore, form a learning community.

\section{The transformation from normal education to teacher education}

Normal education is named after the characteristics of educational activities. It is single-column and closed. It is mainly classified into disciplines. Teacher education is named after the future occupation of educational objects. It is open and comprehensive. It is classified and built based on the combination of disciplines and industries[6]. Therefore, the change from normal education to teacher education is an inevitable requirement of social development.

\section{THE COMBINATION OF JOINT COURSE AND THE ABILITY OF INCLUSIVE EDUCATION TEACHERS}

\section{A. Joint courses overview}

The joint course, originated in the United States, is a form of curriculum expression for learning community teaching models. The principle of the joint course is to help students master the courses they need to acquire and improve their learning effects. The most classic joint course is the attachment joint, that is, the combination of learning methods and specific courses; the other joint course is the combination of specific courses and specific courses [7]. This article takes the preschool education as an example. The joint course discussed refers to the "attachment" joint of specific courses and learning methods, avoiding the disconnection between theory and practice, and highlighting the characteristics of effective learning migration about related courses. On the other hand, it refers to the "parallel" joint of specific courses and specific courses, avoiding duplication and redundancy, and highlighting the speed and efficiency about related courses.

Chinese scholars have only explored joint courses for 20 years. They differ from American scholars in the expression of joint courses, such as "Joint Curriculum" and "Integrated Course Instruction". The commonality of joint curriculum exploration is to construct a course group or course module based on the relevance of multiple courses, to some extent circumvent the drawbacks of redundancy, repetition, and disconnection between theory and practice caused by the lack of mutual care in the traditional teaching.

\section{B. The establishment of the professional competence of the inclusive education teachers}

As an important pre-service training institution for inclusive education teachers, the primary premise is to establish the ability of inclusive education teachers. Under the impetus of the concept of inclusive education, many scholars have discussed the ability of inclusive education teachers. Researchers such as Meng Wanjin, believe that the division between "general education" and "special education" should be broken up, breaking through the limitations of the traditional "linear" ordering or "surface" paralleling of the professional quality of general education and special education teachers[8].

The domestic and foreign scholars' discussion on the structure of teachers' special education ability mainly focuses on the professional concept of inclusive education, professional knowledge and professional skills. The author's point is to increase professional care and focus on the spiritual growth and 
caring ability of inclusive education teachers on the basis of the above three systems. Educational activities should be a vital activity. Caring for a person, its most important significance is to help him grow and self-realize[9]. Therefore, this article constructs a model of the ability of inclusive education teachers with professional care as the core, professional concept as the soul, professional knowledge as the main body, and professional skills as the pillars.

\section{The combination of the joint course and the ability of inclusive education teachers}

The traditional course is mainly carried out in a relatively independent way. The traditional model is beneficial to cultivate students' abstract thinking ability, but it is not the most effective way to cultivate students' practical ability. Because of the limited period of credit, it is inevitable that theory is emphasized comparing with practice, intellectual factor is emphasized comparing with non-intellectual factors. It is obviously difficult to achieve the training objectives of "professional skills" and "professional care" in the capacity of teachers of inclusive education, which is not beneficial to the application-oriented training. Inclusive education teacher also includes teachers of kindergartens, primary schools, and special education schools, as well as community educators. The requirements for applicability, flexibility, and efficiency are particularly high.

The implementation of the joint course is beneficial to break the mode of independent teaching of related courses. The teaching starts from the introduction of common problems or the task of multiple courses, and achieves efficient learning through joint preparations, task arrangements, task solvings, task summaries, etc. Its objective is to cultivate students' practical ability and to realize the association and synchronization of theory and practice through organic integration in the whole process of course teaching.

\section{THE FORM OF JOINT COURSE CONSTRUCTION IN THE TRAINING OF INCLUSIVE EDUCATION TEACHERS}

\section{A. Construction of interactive teaching mode}

In the idea of joint course construction, the work procedure is "the analysis of professional job, refining typical work tasks, identifying action areas, learning area design, and constructing a joint course system". Therefore, in the course, it is necessary to establish course system that reflects the professional core competence and extended course system that reflects the competence of diverse learning support services. This joint course promotes the integration of theory and practice with an interactive teaching system. The course optimizes the teaching through the integration of on-campus and off-campus, in-class and extra-curricular, and theory and practice according to actual needs. This arrangement reshapes the cognitive process of teacher candidates. Modern education must return to life. Because "life is in development, and continuous development, continuous growth, is life."

\section{B. Constructing of learning community}

\section{1) Learner (Student)}

The learners of the joint course are mainly students of preschool education and primary education profession. On the online platform of the course, the learner team has added kindergarten teachers, special education school teachers, and community education workers.

\section{2) Assistant (Teacher)}

The assistants of the joint course are mainly composed of professional teachers of colleges, as well as teachers of special education schools and children's rehabilitation training institutions.

\section{Joint course construction based on professional ability}

\section{1) Professional concept}

The first joint courses are "Education Policies and Regulations", "Early Childhood Education Policies and Regulations", "Special Education, Inclusive Education Laws and Regulations", and "Teacher Professional Ethics". These are mainly the combination of policies, regulations and professional ethics. The connection point is formation of a correct education concept for teachers, especially the formation of an inclusive education concept. In the policies and regulations, it organically integrates the content of early childhood education, special education, and inclusive education, and break into the content of the professional ethics of teachers in the professional ethics of teachers.

The second joint courses are "Children's Philosophy" and "Children's Spiritual Growth Theory". The connection point is the establishment of scientific children's concept of inclusive education teachers.

\section{2) Professional Knowledge}

The first joint courses are "Preschool Child Development Psychology" and "Special Child Psychology". The connection point is psychological knowledge of inclusive education teachers.

The second joint courses are "General Pedagogy", "Special Pedagogy ", and "Introduction to Inclusive Education". The connection point is knowledge of education of inclusive education teachers.

The third joint courses are "Theory and Practice of Preschool Inclusive Education "and "Preschool Children's Family Education and Community Education". The connection point is the knowledge for preschool children to build the three-in-one education field of families, kindergartens and communities.

\section{3) Professional Skill}

The first joint courses are "Pre-school Education Teaching Method and Training Guidance" and "Special Children's Lifeoriented Teaching Method". The connection point is the formation of the organization and implementation ability of teaching activities of inclusive education teachers. Among them, the life-oriented teaching will invite teachers with more experience in educational institutions such as kindergartens and special education schools to participate in teaching activities. 
The second joint courses are "Diagnosis and Assessment of Special Child", "Children's Rehabilitation Training and Behavior Correction", and "Sign Language". The connection point is the formation of the ability of diagnosis and assessment of inclusive education teachers.

\section{4) Professional Care}

The joint courses are "Professional Growth of Teachers", "Happiness and Education Lectures", "Love Art Lectures". The connection point is the cultivation of professional care and the improvement of the ability of love.

On the one hand, the main content of the joint courses is around professional competence, and the content of the course is to take care of each other to provide theoretical support and practical opportunities for the formation of certain professional competence of the teacher candidate. For example, "Preschool Children's Development Psychology" and "Special Children's Psychology" are both professional knowledge and professional concepts. "Diagnosis and Assessment of Special Child", "Children's Rehabilitation Training and Behavior Correction", and "Sign Language" are both professional skills and professional knowledge. "Professional Growth of Teachers", "Happiness and Education Lectures", and "Love Art Lectures" are both professional care and professional concepts.

On the other hand, in addition to the necessary and different perspectives of content cross, in order to improve the structural validity of the joint courses, it is necessary to reorganize and optimize each course. On the basis of the construction of the main courses, the proportion of thematic resources such as short, flexible and targeted activity cases and expert microlecture will be increased. The content of the inclusive education teaching strategies and skills is also reflected in the teacher training, such as Special Children's Life-oriented Teaching Method, Diagnosis and Assessment of Special Child, etc., to help the teachers candidates understand and master the knowledge and skills about difference teaching, cooperative teaching, classroom management, function behavior assessment and active behavior support, enable them to effectively deal with the challenges of work [10].

\section{SUMMARY AND OUTLOOK}

The application value of this research is mainly reflected in two aspects. First, the economic benefits. The joint course will be included in the talent training program, it will also become a characteristic direction of professional training. In addition, teachers in special education schools, kindergartens, primary and secondary schools, and community educators can also use this network platform for independent training. Second, social benefits. Special children groups as a non-negligible social member, its growth should receive the attention of the whole society, a large number of high-quality managers and professional teachers will effectively improve the quality of inclusive education, thereby improving social concepts, presenting practical and effective reform ideas for the inclusive education system.

The optimization of the interactive teaching system makes the learning field gradually expand from the school to the extra-school. The construction of the course network platform makes the study break through the limitations of time and space, and provides favorable conditions for the intervening of the industry teachers. Focusing on the attention and record of learning process of the teacher candidates and multi-evaluation can become a reality. The training of teacher candidates is changed from "normal education" with the acceptance learning to "teacher education" with experiential learning. The practice base for the construction of demonstration and inspection courses is the community. The article explores how to provide appropriate support for children with special educational needs through supportive education concepts, create the educational environment with the least obstacles, and stimulate the potential of vulnerable children to win with dignity and fairness. The joint course realizes the dynamic response of the course and teaching reform in design-source and the process of implementation. At the same time, it promotes the development of local inclusive education.

\section{REFERENCES}

[1] Ju Luxiu. Curriculum Reform in Ordinary Higher Normal Institutions under the Background of Inclusive Education. Journal of Kaifeng Education College, 2014,8:131-132. (In Chinese)

[2] Peng Xingpeng, Lei Jianghua. On the Dilemma of Inclusive Education: Analysis Based on Four-Dimensional Perspective. Journal of Education,2013,12:59-66. (In Chinese)

[3] Lu Youquan. A hundred years of incitement. Jinan: Shandong Education Publishing House, 1997.178. (In Chinese)

[4] Doll. Postmodern Perspective on curriculum. Wang hongyu(Translation). Beijing: Educational Science Publishing House, 2000.146-158. (In Chinese)

[5] Feng Yajing, Wang Yan. The Enlightenment of the Pre-service Training Project of the "Double-Certificate" Inclusive Education Teachers in the United States. Chinese special education, 2015,3:65-71. (In Chinese)

[6] Hao Wenwu. The inevitability and scientificity of the transition from normal education to teacher education. Educational Research,2014,3:127-131. (In Chinese)

[7] Liu Jing, Zhou Zhigang. Joint Course Research of American Professional Courses and General Courses. Chinese vocational and technical education,2016,27:89. (In Chinese)

[8] Zhu Nan, Lei Jianghua. Research on the Cultivation of Special Education Ability of Free Normal Students under the Background of Inclusive Education. Chinese special education,2014,2:29-35. (In Chinese)

[9] Zhao Xuexia. On the new requirement for teachers' quality in the care theory of Noddings. Foreign education research,2003,3:25-28. (In Chinese)

[10] Lei Jianghua. On the Discipline of Special Education in China. Journal of Central China Normal University (Humanities and Social Sciences Edition ),2005,4: 132-136. (In Chinese) 